\title{
THE GHOST IN THE CITY INDUSTRIAL COMPLEX: LE CORBUSIER AND THE FASCIST THEORY OF URBANISME
}

\author{
Simone BROTT \\ Queensland University of Technology, Gardens Point Campus \\ School of Design, D-Block 2 George Street, Brisbane QLD 4000, Australia \\ E-mail: simone.brott@qut.edu.au
}

Received 14 December 2015; accepted 17 March 2016

\begin{abstract}
In 1927 le Faisceau's newspaper Le Nouveau Siècle printed a feature "Le Plan Voisin" on Le Corbusier's 1922 redesign of Paris, including an extract Le Centre de Paris from his Urbanisme (1925). Le Corbusier's book was considered the "prodigious" model for the Fascist state that the league's leader Georges Valois called La Cité Française - after his mentor the French engineer and revolutionary philosopher Georges Sorel, who, originally on the radical left, would eventually be credited as the parent of twentieth-century fascist thought. Valois and Le Corbusier had inherited the longer genealogy of French thought from the turn of the century, namely the bitter opposition to the French revolution, and quarrel with the Enlightenment that was characteristic of many French intellectuals in the early twentieth-century. The final page of Urbanisme features a painting depicting Louis XIV ordering the construction of les Invalides (1670). "Homage to a great urbanist: This despot conceived great things and realized them." The image was produced at the dawning of the French enlightenment: its contents would become the precise object of the fin de siècle reactionary movements of the 1880s that gave birth to le syndicalisme. Le Corbusier thereby historicises his project for the new Paris.
\end{abstract}

Keywords: Le Corbusier, Fascism, architecture, urbanism, Valois, modernism.

\section{Introduction}

Le Corbusier participated in an urban dialogue with the first group in France to call itself fascist: the journalist Georges Valois's militant Faisceau des Combattants et Producteurs (1925-1927), the "Blue Shirts," inspired by the Italian "Fasci" of Mussolini. Le Corbusier's portrait photograph materialised on the front cover of the January 1927 issue of the Faisceau League's newspaper Le Nouveau Siècle edited by the former anarcho-syndicalist journalist Georges Valois, its leader, who fashioned himself as the French Mussolini. Le Corbusier was described in the Revue as one of les animateurs (the "organisers") of the Party (Winter 1927) - meaning a member of the technical elite who would drive the Faisceau's plans. On 1 May 1927, the Nouveau Siècle printed a full-page feature "Le Plan Voisin" on Le Corbusier's 1922 redesign of Paris (Fig. 1): the architect's single-point perspective sketch appeared below an extract lifted from the architect's original polemic Le Centre de Paris on the pages of Le Corbusier's second book Urbanisme published two years earlier, a treatise on urbanism (Valois, 1 May 1927). ${ }^{1}$ Three weeks later, Le Corbusier presented a slide show of his urban plans at a fascist rally for the inauguration of the Faisceau's new headquarters on the rue du faubourg Poissonniere, thereby crystalising the architect's hallowed status in the league. A glittering panegyric by Valois followed in Valois's article "La Nouvélle Étape De Fascisme," in the New Century 29 May:

It is with a very precise intention that we invited Monsieur Le Corbusier to give a lecture. I am totally ignorant of $M$. Le Corbusier's political ideas. What I do know is that his work magnificently expresses, in forceful images, the profound tendency of the Faisceau (Valois 1927a). ${ }^{2}$

\footnotetext{
1 Extracts are from "Le Centre de Paris" and "Chiffres \& Réalisation" in Le Corbusier (1980). The sketch is a rendering of a perspective in "Une ville contemporaine: la Cité, vue de l'autodrome de "grande traversée"' in ibid. Ville Contemporaine formed the basis for the Plan Voisin scheme which follows.

2 Author's translation. From hereon all English quotes are author's translation unless otherwise indicated.
} 


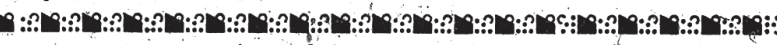 Le PLAN VOISIN}
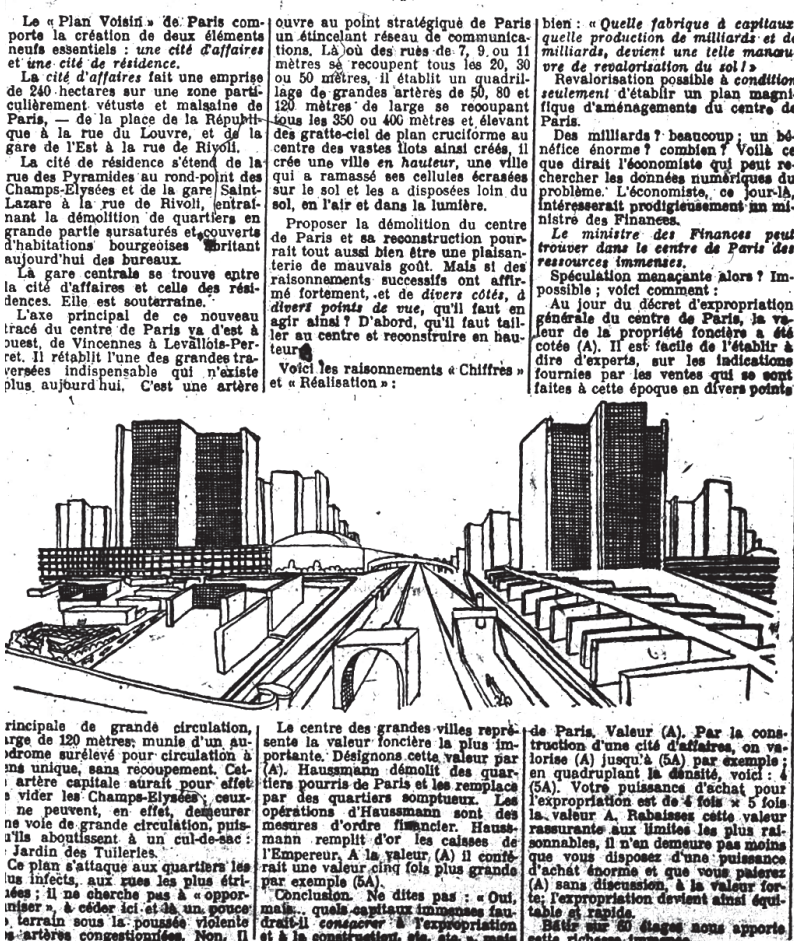

Fig. 1. Newspaper image, George Valois, "Le Plan Voisin," 1 May 1927, Le Nouveau Siècle

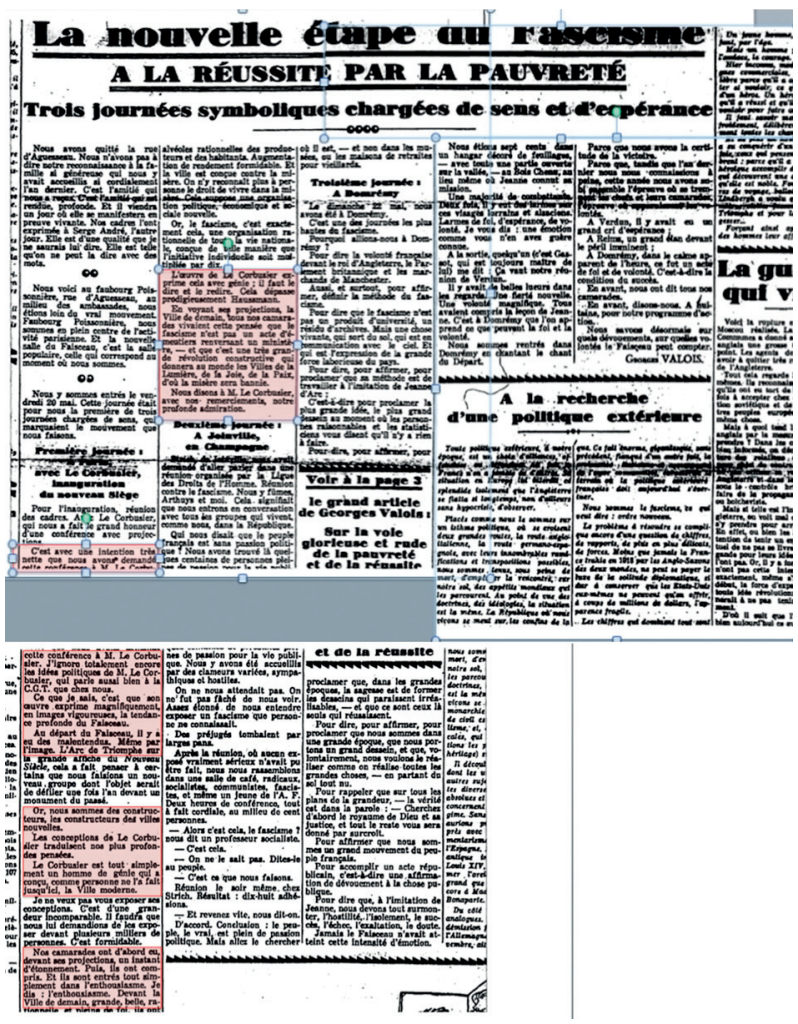

Fig. 2. Valois's review of Le Corbusier's urban slides, Georges Valois, "La nouvelle étape du fascisme: a la reussite par la pauverté," 29 May 1927, Le Nouveau Siècle
Valois reiterates this manifesto in four variants in his review: We are builders, builders of new towns, and Le Corbusier's designs reflect our most profound thought. Le Corbusier is simply a man of genius who conceived, as nobody until now, the modern city.

Our comrades, who were the first to see Le Corbusier's slides, experienced a moment of astonishment. They saw their own thought materialized in The City of Tomorrow.

Le Corbusier's grandiose designs express the profound thought of fascism, of the fascist revolution (Fig. 2).

[and finally] Seeing his slide images of the City of Tomorrow, all our comrades lived this thought that fascism is not an act of rioters overturning a ministry - rather, this is a constructive revolution that will give to the world the modern city.

The symmetry between fascism "un ordre nouveau" and "la cité nouvelle" in Valois's voice, is clear: "Le fascisme: c'est la cité nouvelle" - Fascism is the new city, Valois proclaimed baptising the Faisceau reader in Capital letters, as "LES CONSTRUCTEURS DE L'ORDRE NOUVEAU" the builders of the new order (Valois 1927c).

Valois disavowed having any intelligence of Le Corbusier's political ideology (Valois 1927a), but it was not Le Corbusier's philosophy per se but his construction of the problem via the apparatus of the architectural image to which Valois was responding (Valois 1927a). The question is, What did Valois and le faisceau see in Le Corbusier's slides that warranted this spectacular reception? Was there a symmetry between their schemes and ideologies, and if so what was the historical nature of this exchange?

Le Corbusier's involvement with le faisceau has been known to the English speaking academy since 1983. It was discussed in Mary Macleod's dissertation Urbanism and Utopia, and detailed in the art historian Mark Antliff's essay on Le Corbusier and George Valois in 1997; it was revisited in Simon Richards' book in 2003 , and resurfaced a decade later in two new contested French-language books by journalists Xavier de Jarcy and Marc Perelman in 2015 (Mcleod 1985; Antliff 1997; Richards 2003; Jarcy 2015; Perelman 2015). Yet the social record of Le Corbusier's fascist activities on the ground in 1927 cannot alone clarify the intellectual genealogy of those ideas in French thought that would allow us to reflect on them historically. As will be argued, Le Corbusier's urban images are a form of critique that stand at the centre of this debate precisely for what they reveal and conceal about French history. This 
essay will examine the intellectual exchange between Le Corbusier and Valois, sparked by the publication of Urbanisme, ${ }^{3}$ by tracing the longer historical trajectory of European ideas since the eighteenth century that made this dialogue both possible (intelligible) and compelling to its agents.

\section{The Syndicalist city}

As Mark Antliff first discovered, Le Faisceau did not misappropriate Le Corbusier's plans, in some remote capacity, which might be assumed upon reading Valois's highfalutin prose. Rather, Valois's organisation was premised on the redesign of Paris by the singular medium of Le Corbusier's architectural imaginary. The book Urbanisme which culminates in the Plan Voisin images was considered the "prodigious" model for the fascist state Valois called $L a$ Cité Française (Antliff 1997, 2007) ${ }^{4}$ - after his mentor the French engineer and philosopher Georges Sorel, who after the 1920s would be credited as the parent of twentieth-century fascist thought, cited as key inspiration by both Hitler and Mussolini (Gentile, Mussolini 1935, 1932).

A year before Le Corbusier presented his urban slides to le faisceau, Valois produced his own syndicalist plan for the centre of Paris, which, as he detailed in his book le fascisme (1927) was to be constituted by separately articulated corporate industrial entities (les syndicates). A grand "Assembly" would be created by "delegates from syndicats and corporations of producers," comprising "worker syndicats," "property owners," "tenants," and delegates from every region and district. The Assembly would elect a "Directory" of representatives from each constituency, to superintend major urban projects to carry out the development of "Greater Paris." The directory would establish a high "commission," of experts in "the modern organization of cities that would cooperate with "worker and employee syndicats" and regional authorities to develop new infrastructure for Paris. Under the advice of the commissioners, different industries would form clusters around a single corporative entity, regulated by distribution centers, with the capacity to transport goods en masse through a proposed new network of freeways (Valois 1927b; Antliff 2007).

\footnotetext{
3 This essay focuses on Le Corbusier's early not later thought when Le Corbusier was more politically active, because the goal is to understand the founding ideas of his career. The 1927 encounter with Valois is of capital importance in understanding Le Corbusier's "fascism" given le faisceau were the first fascist group.

4 Antliff's 1997 essay was the first discussion on this subject. Author is especially indebted to Antliff for his work and advice.
}

Valois assigned "an economic and social bureau" to every sector of Greater Paris, in which "the producerbosses, technicians, and workers would be able to hold local meetings, regulate their intersyndical affairs, and organize the social life of the sector," and a "bureau of housing" where "construction societies" in parallel with "syndicats and communes" would plan urban development. The Bureaus would dissolve class conflict as the modern city would be "nothing other than the fasces of all energies, all the wills behind technical, social and national progress" (Valois 1927b; Antliff 2007). Valois's technocratic dream described a vast factory or industrial complex - where the purpose of life for each citizen was to devote one's life to erecting the city, and ipso facto to recover for the nation the glory of work. 1927 was the same year the Berlin film Metropolis was released, an acid satire on the very technocratic fantasy of the city industrial complex.

Valois's model shared an obvious ideological and organisational parity with Le Corbusier's Plan Voisin both schemes were based on Taylorist methods of production and the valorisation of labour. Le Corbusier and Valois both loved Henry Ford and believed in Taylorism: a scientific system for increasing the productive flow of factory processes (Mcleod 1983). By the time Le Corbusier had completed the Voisin plans in 1922, he and Amédée Ozenfant had already published serial agit prop issues on Taylorism and Fordist method in Esprit Nouveau (Le Corbusier 1921b; Le Corbusier 1921a; Le Corbusier 1923; Le Corbusier 1925a). Three years later Le Corbusier would join Ernest Mercier's movement the Redressement Francaise that promoted the industrial ideas of the engineer Frederick Winslow Taylor. But a longer view is necessary, for Le Corbusier's fascination with the anarcho-syndicalist theory of the French city in 1927 invokes the entire trajectory of industrial ideas and glorification of labour in French thinking about cities since the eighteenth century, exemplified in the figures Henri de Saint-Simon and Charles Fourier. Furthermore, it is the singular reemergence of this line of technocratic ideas in the revolutionary chassis of French syndicalisme whence the meeting of Valois and Le Corbusier becomes significant for modernist history.

\section{La cité guerrier}

In his book le fascisme, Valois wrote that his principal inspiration and the birth of European fascism came from Sorel's Réflexions Sur La Violence (Sorel 1912; Sorel, Hulme 1914), adducing Mussolini's famous attribution: "it is neither to Nietzsche, nor to William James that I owe a debt, it is to Georges Sorel" "le père intellectuel de fascisme" (Valois 
1927b). As evidence, Valois produced Sorel's chapter "Violence and the Decadence of the Middle Class" (Valois 1927b) in which Sorel compared the fascist revolutionaries to Spartan heroes: Let us salute the revolutionaries as the Greeks saluted the Spartan heroes who defended Thermopylae and helped to preserve the civilisation of the ancient world (Sorel 1912; Sorel 1999). Sorel admired classical Greece as a society "dominated by the idea of war conceived heroically," that its institutions "had as their basis the organisation of armies of citizens" (Sorel 1999; Antliff 2007). Sorel projected these classical ideas onto the French "producers" of la cité.

Sorel like many French intellectuals in the early twentieth century, including Valois and Le Corbusier, decried France's invention of a bourgeois modern democracy and the classical liberalism spawned by the French revolution - he opposed the entire rationalist paradigm of the French enlightenment. La cité was conceived by Sorel as a "spiritual unity" to foment the moral regeneration of the French masses. Through its central "myth" of the "general strike" la cité would overturn democracy and capitalism by proletarian violence that would instill in each citizen the warrior values of ancient Greece (Sorel 1999). In his first book Vers une architecture, Le Corbusier had opposed the "decadence" and commercialism of the French bourgeoisie; and, using the same historiography as Sorel, denounced the French Revolution, and offered the age of classical antiquity as the solution: the Parthenon, Paestum, and Hadrian's Villa were the formal quintessence of l'esprit nouveau. Le Corbusier, Sorel, and Valois - with almost no variation - substituted the pacifist values of laissez faire capitalism with the military values of the Greek Polis. The war not only stimulated productivity; but, heroism in the battlefield and creativity in industry are tantamount in both Le Corbusier's "warrior esprit" and Sorel's idiom "the warrior of the city" (Sorel 1999).

Valois asserted the new fascist order would be achieved through the physical reconstruction of France after the first world (Antliff 2007). His larger project was to translate Sorel's "La cité" into a new model for Paris, that would synthesise Sorel's "morality of the producers" and "morality of the combatant" (Antliff 2007). Le Corbusier was not merely interested in efficiency and rationalisation, but in Hellenic militancy and l'esprit guerrier that would ignite industry (Antliff 2007).

In 1917 Sorel began writing a new book on la cité, De l'utilite de pragmatisme published in 1921 that retreated from the manifesto on militancy to reflect on history (Roth 1980). It is in that book that Sorel provides an historiography of French Art strikingly similar to Le Corbusier's polemics.
Sorel articulated four historical cités: the cité savante, cité esthetique, cité morale, and cité catholique (Sorel 1928; Stanley 1981; Antliff 2007). ${ }^{5}$ Reading from Viollet-le-Duc, the cité esthetique, was originally a corporation likened to a classical "aristocracy of professionals" whose aesthetics were based on classical proportions and rules of formal construction (Stanley 1981). These classical references had military significations: for "the "military symbolism, of the façade of Notre Dame de Paris mimicked the gates of a Roman fortress" (Stanley 1981). The cité esthetique was praised as an "art of producers" that reformulated the classical language and Greco-Roman building techniques in a "critical spirit" (Stanley 1981). However, the cité esthetique was destroyed when the artists "abandoned the community of artisans to mix with courtiers, humanists, and rich bourgeois." The cité was fractured into specialisations, and the process of social aggrandisation of artists and architects over artisans, resulted in artistic materialism and decadence, as the classical model was abandoned. The plutocrats commissioned the artists to produce frivolous "forms of art" such as "erotic mythologies" while the architects "instead of trying to construct well-planned buildings, painted vast decors" for palace interiors (Stanley 1981). Architects were given to "design pretentious decorations, which are only capable of emphasizing the glorification of money" (Stanley 1981). "Once again Sorel blamed the pernicious influence of the Enlightenment for this artistic decline. Having completely rescinded its autonomy by the eighteenth century, the cité esthetique's fate was sealed when its members endorsed the Enlightenment's attack on the ancients and championing of the moderns" (Antliff 2007).

\section{Le Corbusier's homage to Louis XIV}

In 1912, Le Corbusier condemned the French Revolution of 1789 which with its "idées égalitaires" was "désastreuse pour l'Art” (Le Corbusier 1968; Brott 2013). Le Corbusier's book Urbanisme ends with a reactionary image that not only reveals his view of French history, but defies his devastating project for a modern city that would entirely break with the past (Le Jeune de Boulencourt 1683) (Fig. 3). ${ }^{6}$ On this page, Le Corbusier admires a drawing of 1683 depicting Louis XIV ordering the construction of les Invalides. His caption is addressed to Louis XIV himself: "to a great urbaniste: This despot conceived great things and realized them. The brightness of his glory covers the country, everywhere. He was able to say: I desire! or such is my

\footnotetext{
English translation cited in Stanley.

6 The original source of the figure is the Frontiscipe by Le Jeune de Boulencourt to the book
} 
pleasure." Le Corbusier, here, is not concerned with the architecture of Mansart or Bruant but with the order of authority. The caption is followed by ceci n'est pas une declaration d'Action Française - because for Le Corbusier these ideas preceded the Action Francaise party of the twentieth century, and are to be found in prior architectural history.

In a perfect world 100 years before the French Revolution an angel (the transcendent authority hovering over la cité) looks down from the sky, sounding a trumpet meaning "the kingdom of the world has become the kingdom of god, and he will reign for ever and ever" - this is the theological world view that French enlightenment thinkers like Voltaire, Jean-Jacques Rousseau, and Montesquieu would begin to challenge (Montesquieu 1949; Rousseau 2005; Voltaire 1996 [1737]; Voltaire 1762). God here, and not rationality or an enlightened democracy, is the arbiter of authority. The uncontested master designated by God, Louis XIV orders the construction of les invalides (1670) a home for military patients, today a military museum of the Army of France - while a mysterious dark figure in the foreground holds out a note to the sun king. On this site converged critical French history. The invalides was stormed by Parisian rioters for ammunition against the Bastille, Napoleon was buried under the dome (1840), and in 1894 the fascist degradation of Alfred Dreyfus was held at the main building. The etching is a shrine to war and domination - it is homage to a preenlightenment, pre-revolutionary order of despotism and the French aristocracy.

Le Corbusier hereby closing his book suggests modernity is inseparable from militancy, and that the "aestheticisation" of violence under despotic orders, to evoke Walter Benjamin's famous passage, is essential to achieving great works, and to the avant garde itself, a belief Benjamin predicted would be tragic for Europe (Benjamin 1968). The privileged architectural image for Le Corbusier is not les invalides, but the architectural vindication of a totalitarian world. Importantly, this image was produced at the dawning of the French enlightenment; its contents would become the precise object of the fin de siècle reactionary movements of the 1880 s that gave birth to proto-fascism in France (Remond et al. 1954; Weber 1964; Gentile, Mussolini 1935). Le Corbusier's appeal to Louis XIV in 1925 reveals in symptomatic fashion the genealogy of modernity in France's long history of despotism and violent constructs.

\section{The paradox of syndicalisme: the master and the masses}

Yet the paradox in anti-enlightenment thought - and one that became a problem for Le Corbusier - is that

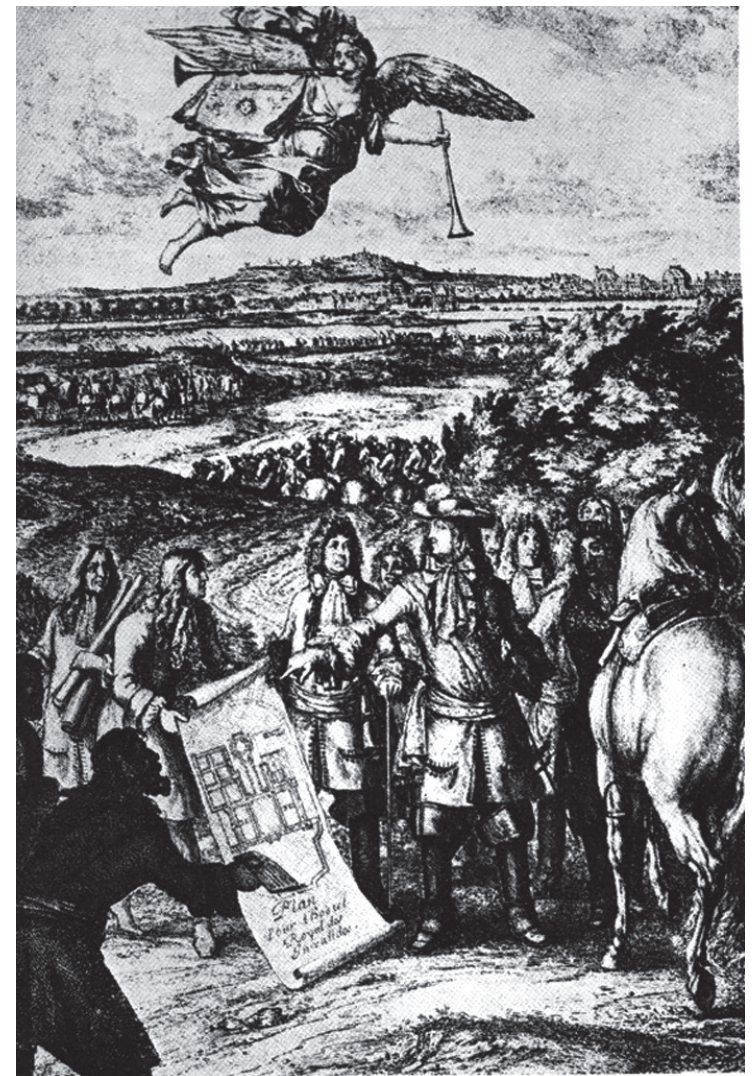

Fig. 3. Louis XIV ordering the construction of les Invalides, "Homage to a great urbanist" Le Corbusier's caption in Le Corbusier, Urbanisme, 285

of despotism (the master) and the syndicalist goal of class inclusiveness (the collective "will").

For Sorel, the figures in la cité are the result of "the will" of the "combatant-producers" who build the town. Sorel substituted the hierarchical structure of capitalism with the diffusion of authority down into the workers' organizations. By flattening all class members onto a single level, syndicalism claims to bring about authentic representation, a "morality that turns the men of today into the free producers of tomorrow, working in workshops where there are no masters" (Sorel 1999). For Le Corbusier too the subject does not exist outside the "collective will" that realises the city. "Collective will is the state of mind of an epoch which is capable of application to the mass of men as well as to the individual, by means of those great successive movements which are at once an education, a disintegration, and a renewal; it is something which cannot be adulterated...since it provides for the multitude a single outlook and a unanimous sensibility. With a cold and clear accountancy the + and - of an epoch are established. A way of thinking... arises. The collective is "the torrent of mankind." (Le Corbusier 1971). 
While Sorel affirms there would be no masters in the new city, nonetheless - like Le Corbusier - la cité would be constituted by the elite, the most brilliant "producers" who would regenerate the city. For Valois again "the elite leaders of industry, the technicians, and the strongest faction of the working class" would bring about the revival, even while he claimed all classes would be equal. Le Corbusier similarly separated housing from industry, yet was much more elitist than Sorel or Valois, who did not separate residential districts by class like Le Corbusier's infamous segregation of the 'masters' from the masses who would be banished to the periphery of the town in satellite cities (Le Corbusier 1980).

Sorel is alive to the problem of the master which he traces back to the French revolution. He argued that the Rousseauesque organisation that mobilised the French revolution believed that it alone possessed the secret of the general will, thereby justifying their limitless authority: "this conceit was now entertained by a class of intellectuals who had turned themselves into the people's masters" (Sorel 1999). The revolutionaries de facto preserved "the principle of hierarchy," so their violence was unjustified. But is there not another schism in Sorel's ideas? For the fascist city conceived as "collective will" symptomatically invokes an Enlightenment philosophy buried in Sorel, namely the influence of Rousseau, for whom the notion of volonté générale (collective will) is linked to the idea of political representation: to 'stand in' for someone or a group of subjects i.e. the majority vote, the basis of democracy and liberalism (Rousseau 1789; Bernardi, Rousseau 2002; Rousseau 1829).

\section{Ni droite ni gauche}

Zeev Sternhell locates the rise of fascist ideology across Europe in the "anti-materialist" transformation of Marxism that took place in France after the first world war, which opposed classical liberalism and the rationalist ideology of the French Revolution. The first seeds for French fascism were planted by Sorel's leftist students who violently rejected the material values of bourgeois capitalism, and decried the Marxist view that socialism issued from class struggle (the emancipation of the proletariat). In Reflections on Violence Sorel substituted the concept of the working class and the material "State" with that of "la nation" - a spiritual totalité that would stage the bourgeoisie and proletariat in a grand battle. It was precisely Sorel's idea of a dematerialised body emptied of classes, but united by ésprit, in a word: La Cité, which took over the proletariat and materialist interpretation of history - in this perversion of Marxism that would so disfigure the twentieth century. Sorel's ideological biography traces an intellectual trajectory that can be paralleled to that of Valois and the early Le Corbusier - because they issued from the same historical ground. ${ }^{7}$

In the late 1880s, Sorel wrote essays on architecture, political history, and philosophy influenced by Ernest Renan, Aristotle, and Hippolyte Taine. In 1893, he declared himself a Marxist and a socialist, through his reading of Proudhon, Karl Marx, Giambattista Vico, and Henri Bergson. The ideological ambiguity of Sorel's sources has been noted by Hamilton (James Jay Hamilton 1973). He wrote for the earliest French Marxist journals but by the turn of the century was active in the "revisionist debate" and "crisis of Marxism." Through his contributions to Enrico Leone's Il Divenire sociale and Hubert Lagardelle's Mouvement socialiste, around 1905, he advanced the theory of revolutionary syndicalism (Neilson 1919). In 1906, his essay Reflections on Violence appeared in Mouvement socialiste, later published as a book in 1908, and followed by Illusions du Progrès. Against the Confédération générale du travail in 1909-1910 he joined Maurras' Action française, a collaboration that would inspire the Cercle Proudhon (James Jay Hamilton 1973). In his groundbreaking book Ni Droite ni gauche on the significance of French fascism to Europe, and the French origins of philosophical fascism, Zeev Sternell identified an intrinsic tension and ostensible contradiction in French history:

Is it reasonable to suggest that democratic and liberal France, Jacobin France, nurtured not only the ideology of the French Revolution but also its antithesis? A detached analysis of French history and politics shows that France is not only a country where the prevailing tradition is universalistic and individualistic, strongly rooted in the French Revolution, rationalist, democratic, and either liberal or Jacobin in colouring. It is also a country that, like Germany, gave birth at the end of the nineteenth century to a particuliaristic and organicist tradition, often dominated by a local variant of cultural nationalism that was sometimes, but not always, of a biological and racial character, very close to the volkish tradi-

\footnotetext{
7 While Le Corbusier has been accused of cynicism for his involvement in groups on both 'sides' of the ideological divide throughout his lifetime, Valois's activities and affiliations were no less ambiguous - no better illustrated than the fact that he considered himself the French Mussolini, but ultimately took part in the resistance against Vichy, was captured by Hitler and murdered in a concentration camp. No historian would say Valois or Sorel were confused, as architectural historians have accused Le Corbusier. The ambiguity lies in French fascism.
} 
tion in Germany. From the end of the nineteenth century, this other political tradition launched an all-out attack on liberal democracy, its philosophical foundations, its principles, and their application. It was not only the institutional structures of the Republic that were questioned, but the whole heritage of the Enlightenment.

From the end of the nineteenth century, these two traditions fought each other but also coexisted, often in the same work, in the thinking of the same person, independently of the celebrated left-right dichotomy. The traditional concept of a left-right conflict takes into account the realities of the period only very partially, and it often fails to take them into account at all.

Neither right nor left, fascism therefore united antibourgeois, antiliberal nationalism, and revolutionary syndicalist thought, each of which joined in reflecting the political culture inherited from eighteenth-century France (Sternhell 1996).

The phrase "ni droite ni gauche" was coined by Valois in le fascisme and popularised in French fascist circles in the 1930s. Sternhell writes that the primary example of neither right nor left from the end of the nineteenth century was Ernest Renan who was of course one of le Corbusier's principal influences. Sternhell writes "For Barres, Sorel and Maurras, Renan was a revered intellectual master" (Sternhell 1996) and in the 1930s Mussolini referred to Renan's "prefascist illuminations" (Gentile, Mussolini 1932). "The place given to the writer of the Vie de Jesus in school textbooks bear witness to his status in the republican liturgy and mythology" (Sternhell 1996). As Turner notes, Le Corbusier adored Ernst Renan's book. Turner identified "the largest number of passages which Jeanneret bracketed ... characterises the ideas of Jesus as being "revolutionary" consistent with his markings in Nietzsche which he read at the same time," Le Corbusier strongly identified with the heroic struggle of Jesus. Renan's reading of Jesus' revolution moreover contained the exact $n i$ droite ni gauche duality conceived by Valois: both intellectual (the devotion to spirit) and material or social (the utopian social reformer) - "the revolutionary prophet and the reformer."

Renan was the first to identify the "intellectual and moral reformation" sparked by the defeat of 1870-1871 the Franco-Prussian war and fall of the French Empire. Renan's anti-enlightenment antimaterialist thesis had already been stated in 1869 in an essay prior to the defeat. He opposed "the idea of the equal rights of all men, the way of conceiving government as a mere public service which one pays for..." the very belief "that politics can be reduced to a mere consultation of the will of the majority" (Sternhell 1996). Renan encouraged Napoleon III to adopt "the truly conservative programme," in order to defeat "that materialist conception" of democracy. "Nearly losing all memory of a national spirit, ... [it was] Prussia, which had remained a country of the ancien regime and thus preserved from industrial, economic, socialist, and revolutionary materialism, which vanquished the virility of all the other peoples" (Sternhell 1996). Renan railed against all the forms of perceived materialism: democracy, socialism, "bourgeois materialism" all which had brought France a certain mediocrity since the eighteenth century. The longstanding French critique of materialism (the belief that nothing exists outside of matter) is that it was responsible for la decadence, the atrophy of French morals, art and literature (Sternhell 1996).

Sternell points out that Renan's polemic was repeated in identical form at the defeat of 1940: "In the summer of 1940, materialism was once again made responsible for all the disasters that had befallen the country... Once again, it was materialism that was accused of having eaten away the body of the nation" (Sternhell 1996). But there was an important difference. From the start of the twentieth century, liberal and bourgeois materialism were substituted with Marxist and proletarian materialism - Marxism only became a veritable force by 1890 long after Renan wrote his book. The translation from Renan's critique to those of Sorel, Valois and Le Corbusier was characterised by the opposition to capitalism and to the Marxist version of materialism based on class struggle.

\section{Le Plan Voisin}

The dematerialisation of the modern city was a quintessential feature of both Valois's and Le Corbusier's urban proposals. By increasing the density of Paris four times and concentrating material labour in seven new towers that would constitute the new business centre of Paris, Le Corbusier visualised a vast city of pure air, emptied of persons, who were to be concealed in the weightless, ephemeral gratte-ciel (sky-scraper). While Valois railed against materialism - like Le Corbusier, he proposed concentrating material (labour) in the centre: in both schemata the a mbivalent status of materiality feeds on the old terms of Marxism and revolution while attempting their removal. Le Corbusier writes:

The air is clear and pure; there is almost no noise. What, you cannot see where the buildings are? Look... into the sky towards those widely-spaced crystal towers, taller than any buildings in the world. These translucent prisms that seem to float in the air without an- 
chor to the ground, sparkling at night - are huge blocks of offices (Le Corbusier 1995).

It is a city of Air, or in le Corbusier's words pur création de l'esprit (from spirare to breathe). Le Corbusier proposes an ethereal city, invisible and beyond matter. In fact, Le Corbusier's conception of esprit can be located in the intellectual tradition of German "idealism," namely the belief in the primacy of mind, ideas and spirit over materiality and presence. As I have noted previously, Hegel's post-enlightenment conception of spirit - the Geist that permeates Le Corbusier's thought issued from his art teacher's confirmed ardour for Hegel, Fichte, and Schelling, in a causality as rapidly discovered as it was forgotten in Paul Venable Turner's Harvard dissertation of 1971 (Turner 1977; Hegel 1967b). (The conception of spirit is also intrinsic to the moral-political philosophy of Hegel, an apologist for the totalitarian "absolute state." Hegel like Valois opposed the Enlightenment idea that the individual is free due to his "inalienable rights" and argued for the unification of man with a national whole (Hegel 1967a). According to Turner it was Le Corbusier's profound study of his art teacher Henry Provensal's L'Art de demain that inculcated in the young Le Corbusier the ever-present Romantic ideas and idealist values that directly emanated from the philosophy of Hegel and the German idealist tradition - after Kant - that formed Provensal's framework and which le Corbusier adopted as early as 1904 (Turner 1971). Le Corbusier was also influenced by Hermann Matthesius's conception of architecture as a "supra-material" (spiritual) undertaking; and, Germany at the turn of the century was the crucible of philosophical idealism (Turner 1971; Turner 1977).

Provensal's idealist influence on Urbanisme is evident in Le Corbusier's formal description of the city's

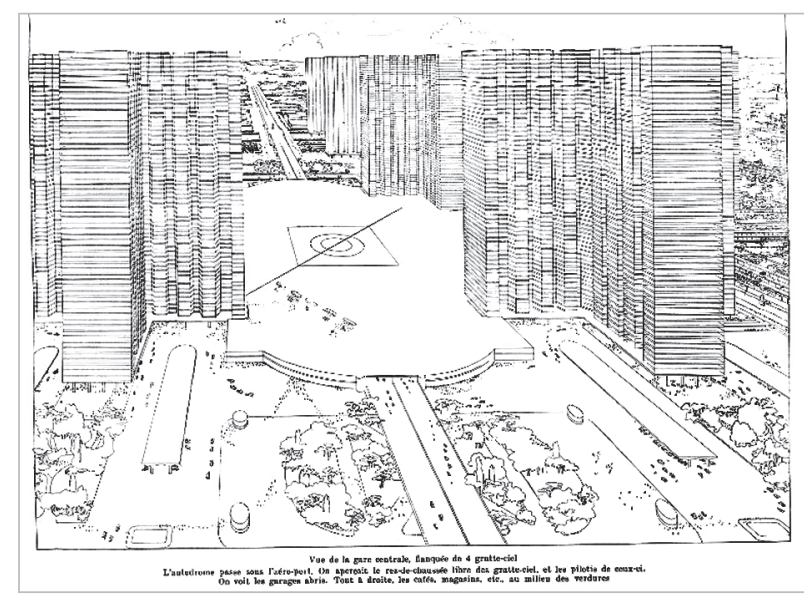

Fig. 4. Plan Voisin perspective, vue de la gare centrale "view of Central station, flanked by 4 skyscrapers" (Le Corbusier 1995) buildings as prisms or crystals. Provensal writes that "mineral crystals" are the ideal type from "nature that has given architecture invariable forms." "Le règne mineral nous offre dans ses cristallisations, des exemples nombreux et invariables de volumes initiaux aux-quels l'architecture peut emprunter des renseignements. C'est donc dans la combinasion rationnelle de ces volumes, que s'effectuera toute l'aspiration de l'art, et c'est bien ce que la nature veut nous donner comme point de départ. En outre, les formations géologiques peuvent inciter l'artiste à des adaptations, à des modèles architectoniques capables d'être inscrits au sein de l'espace" (Turner 1971; Turner 1977). In Provensal's aesthetic manifesto Architecture is "... . l'expression cubique harmonieuse de la pensie” (Turner 1971). Provensal not only gave Le Corbusier the formal-aesthetic method - but the ideological platform - for the idealist city.

The buildings are weightless in Le Corbusier's famous "vue de la gare centrale" perspective; the wireframe striation reads as a thin surface wrapping rather than built fabric or fenestration (Fig. 4). Compare this line work with the heavy treatment of skyscrapers in the ville contemporaine rendering, two pages earlier, drawn from the same location and perspective.

In the plan Voisin perspective, the buildings are inclined planes (cardboard cutouts) against the sky: "The silhouette of buildings against the sky is one of the most fundamental elements in urban aesthetics; it is a thing that strikes the eye at the first glance and gives the final impression" (Le Corbusier 1971). The sky is the ultimate goal of Le Corbusier's new city and the eye is drawn upwards in his perspective to the zenith of the city, the uninterrupted skyline at the top of the drawing. "The profile of the traditional street, given by the chaotic outlines of volumes against the sky... would be replaced by a pure and simple line." The tops of the skyscrapers form a single horizontal line from which hang the translucent volumes. The city for Le Corbusier is a single line through which all other lines are collapsed, all material folds are flattened and all contradictions resolved (Le Corbusier 1995). For Le Corbusier reading directly from Provensal's idealist formula that will be repeated by the architect in almost unaltered form: "geometric volumes are defined precisely by the horizon expressing the eternal Ideal or 'absolute' " (Turner 1977). The Plan Voisin in intellectual terms is a de facto Hegelian paradigm, the perfect unity of la raison and l'ésprit, as expressed in Hegel's triadic framework Reason, Spirit, and Religion in Phenomenology of Spirit (Hegel 1967b).

Le Corbusier's urban philosophy is hence not captured in the plan view of the centre of Paris (plans which have been the focus of historiographical interpretation) 
but in the horizontal perspective, where the elements of Le Corbusier's idealist thought are isolated and laid bare. For Le Corbusier, the apparatus of the horizontal perspective drawing reproduced the apparatus of vision of a real skyscraper: The skyscraper gives rise to a "horizontal vision, that previously only Alpine climbers enjoyed" he rhapsodised. "A wide horizontal perspective can acutely influence us... As the horizon expands, as the eye takes in vast distances, it seems that thought itself can be heard" (Le Corbusier 1980). For Le Corbusier, the skyscraper is an "apparatus for the suspension of time and space itself - an optical look-out for dominating an ordered world" (Le Corbusier 1980).

The horizontal perspective also staged Le Corbusier's conception of the "vertical city," a "city that rises vertical to the sky," counter to the "bewildering flattened city the airplane reveals to us for the first time" (Le Corbusier 1980). This account has a surprising Darwininan (twentieth-century) ring - through the skyscraper, "our city suddenly rises to its feet" - that appears at odds with an idealist framework. The perspective thus has two axes: the horizontal axis of the skyline and the vertical axis given by the rise and rise of the skyscraper, forming a Cartesian coordinate system whose grid of perfect rationality floats in the thin, altitudinous air of Hegelian idealism - in what is a synthesis of French rationalist (modernist) and German idealist (anti-enlightenment) method recovered in the aesthetic picture plane of the early twentieth century. In the horizontal perspective the "morality of the producers" (subsumed by the skyscrapers) and "the master" (the ghostly authority that hovers above La Cité) are flattened into a single picture plane, vanishing all subjects in the spectral city and hence abolishing all representation.

Le Corbusier's elitist, mathematically obsessive scheme appears on the surface to ally itself intellectually to pure rationality and French individualism (mind without spirit, or the trace of Kant in Hegel), despite Le Corbusier's alleged hatred for the values of the French Revolution and anti-Enlightenment sentiments he shared with Valois. The Plan Voisin was more rationalist than Le Corbusier perhaps ever intended despite his Romantic, idealist goals, and the city of pure spirit therefore reverts to the enlightenment myth revolutionary syndicalism first opposed (Horkheimer et al. 2002). Le Corbusier emerges out of this dialogue an intellectual-reactionary responding to French history via German not French philosophy, viz Hegel (via Provensal) and Nietzsche. Yet this tension in Corbusian ideation finds a parallel in Hegel's metaphysics; no less than in the double conception of mind and spirit contained in the German word Geist, which presents the same problem as the French version esprit.

\section{Realism and Le Corbusier's Panorama}

In 1925 Le Corbusier painted a vast horizontal perspective of the redesign of Paris that would appear at the esprit nouveau pavilion at the international exhibition of decorative arts held in Paris and reproduced in Urbanisme: "The voisin plan was on view, I painted a panorama whose aim was to make evident to the eye this new conception, so unfamiliar to us as yet. The Panorama was most carefully executed and showed Paris as it is today from Notre Dame to the Etoile.... Behind it rose the new city" (Figs 5, 6).

Le Corbusier's photo-realistic fifty-square-metre panorama would have been breathtaking to an architectural audience in 1925, like the first Hollywood matte painting. And its purpose was the same, to create a seamless illusion of an environment that would otherwise be too expensive or impossible to realise. Just as Sorel's images of a battle already won lend a disturbing realism to Sorel's myth, Le Corbusier narrated the Plan Voisin city as if it already existed: "Another ramp takes us to a second promenade two stories above the first. On one side of it is a Rue de la Paix of the smartest shops; the other commands an uninterrupted view of the city's limits" - the city is suddenly materialised on the pages of the book (Le Corbusier 1995). In some sense Le Corbusier believes that his city is real, insofar as it is the inevitable result of "a pure logic taken to its fi-

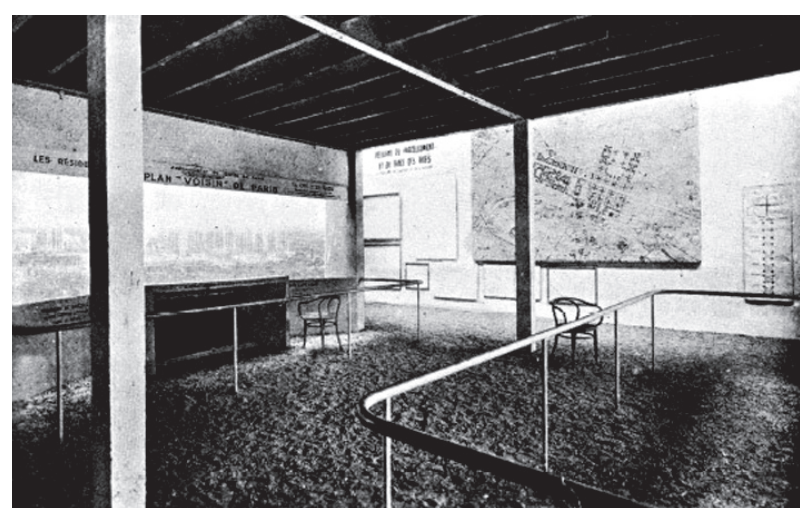

Fig. 5. Exposé au Pavilion de I'ESPRIT NOUVEAU à I'Exposition Internationale des Arts Décoratifs

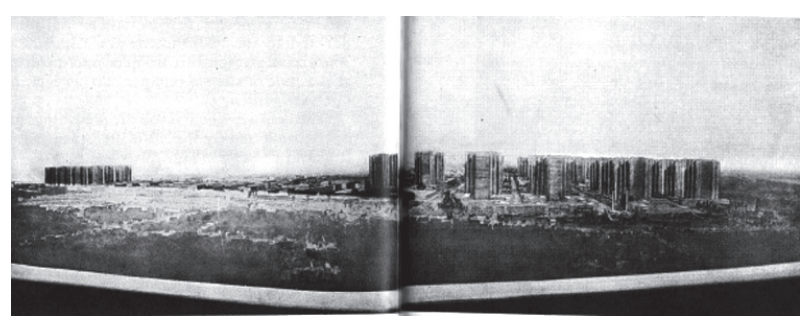

Fig. 6. Diorama du Plan Voisin de Paris (Pavillon de l'Esprit Nouveau à I'Exposition des Arts décoratifs) (Le Corbusier 1980) 
nal conclusion" (Le Corbusier 1971, 1995) ${ }^{8}$ - it exists in the model whose future is assured (Le Corbusier 1980).

Realism importantly forms the lining of Sorel's antienlightenment polemics which sought to replace the unreality of money - the abstraction of finance capitalism - with the social real - a system grounded in "morality" via the desire or "will" of the masses. In Esprit Nouveau, Le Corbusier appealed to society's "violent desires" for modernisation. Le Corbusier's imagery is not merely theoretical or idealistic but imbued with the revolutionary purpose that would ground his proposal in reality. In Reflections on Violence Sorel writes that "fascist myth is a system of images that changes history" (Sorel 1999). "Images or myths are not descriptions of things but expressions of a will to act. A utopia is, on the contrary, an intellectual product for future juridical institutions... while the myth leads men to prepare themselves for a combat which will destroy the existing state of things" (Sorel 1999). To use Sorel's formula, Le Corbusier's new city-centre which rose up from the ashes of Paris constituted for Valois an "image of battle" or "coordinated picture of the revolution to come." Sorel's revolutionary conception of the image and its relationship with Will come from German romanticism. Valois, reading from Sorel, in turn, conceived the Faisceau's task as a problem of the architectural image, in other words, how to visualise la cité.

Le Corbusier was writing Urbanisme at the precise moment that the redesign of Paris was being debated and undertaken by planning authorities, as he urgently narrates: "A Congress of The New Paris is being developed at the moment. What will happen to Paris, what streets will it give us? Heaven save us from the grasping Balzacian delegates of the spectacle of faces in the black crack of the streets of Paris..." Urbanisme was a serious attempt by Le Corbusier to appeal to planning authorities to change the direction of Paris - even if historiography would mistakenly reduce Le Corbusier's urban oeuvre to 'l'utopie' - to something that amounted to little more than a fantasy. The description of Le Corbusier's urban plans as utopian fantasies appears in the 1980s, 1990s, and 2000s (Fishman 1982; Mcleod 1985; Sutcliffe 1977; Colquhoun 1989; Mcnamara 1992; Rowe 1996; Richards 2003; Coleman 2012). By the time the book came out, Le Corbusier had endured widespread objections to his schemata, bad reviews which he would forensically document, publish, and archive in a chapter of Urbanisme. Le Corbusier's "analysis of

\footnotetext{
8 "The following considerations are not fanciful, they are merely, once again, the consequences of a continuous train of thought taken to its logical conclusions..." "pure reason does not make this a utopian scheme, on the contrary belief in pure reason leads to the most concrete and precise solution" (Le Corbusier 1995).
}

various widespread objections to his scheme" was published in the Almanach d'Architecture Moderne, 1925. (133); L’Architecte, Paris September, 1925: L'Architecte, Paris September, 1925 (Le Corbusier 1995).

Sorel's fascist myth was based on the event of palingenesis - viz annihilating the existing order and starting again from degree zero - the sine qua non of bringing the myth to reality. A mythic palingenesis was also lionized in Le Corbusier's Urbanisme in his concept of urban purification, the fatal razing to the ground the existing city, in order to start again ex nihilo, that would catalyse the spiritual rebirth Le Corbusier had in mind (Sorel 1999). Urban purification becomes an historical imperative and ritual for Le Corbusier who re-enacts the historiological narrative of the purification of Paris undertaken by "all the great leaders of France," and in doing so compares himself to Louis XIV and Haussman who succeeded in demolishing large existing fabric to rebuild the city. In his eyes, Urbanisme was neither utopian nor fanciful - history has vindicated these men just as history will vindicate Le Corbusier (Le Corbusier 1980). Valois himself praises Le Corbusier's "productivist" models of urban purification, citing Haussman in his article "Le fascisme : c'est la cité nouvelle" : "the great industrial revolution brought the large army of technicians and great team of builders of the modern world, ranging from baron Haussmann to the prodigious engineering of Le Corbusier."

Le Corbusier's panorama was pivotal in constructing the realist ontology of the city. For Le Corbusier "ce n'est pas d'un futurisme périlleux...C'est un spectacle organisé par l'Architecture" (this is not a perilous futurism, it is a spectacle organised by a real architecture) (Le Corbusier 1980). The panorama existed at the threshold of representation, somewhere between the artefact and its lightweight referent in the infinitely far horizon of the future. (The horizon is not merely a visual term in perspective drawing but a temporal-historical term in Le Corbusier's ideation.) This, finally, is the conception of image in which Valois's and Le Corbusier's dialogues coincide - in what is a dizzying conflation of the image, the modele, the drawing, and the city itself. I propose that the Faisceau understood Le Corbusier's scheme better than his professional colleagues, because they understood it at the privileged level of the architectural image - not as illusion or representation, but as historically concrete event.

\section{Conclusion}

Le Corbusier's urban model resurrects Hegel's Geist in the revolutionary body of the syndicaliste cité - the ghost in the city industrial complex - and that is what 
bound Valois to Le Corbusier. Le Corbusier ostensibly provided to Le Faisceau visual evidence of the fascist myth that will "change history." But what does that image accomplish for ideology that the league's discourse and literature could not? The architectural image of Urbanisme contains and captures in a concise manner all the contradictions of French fascism and the roots of that intellectual conflict in eighteenth century France. For le faisceau, the architectural image is a unit of 'completion,' where the image is made to perform a magical consummation of unresolved arguments and problems that had troubled France for centuries. In equal proportions, the architectural image conceals and reveals the intractable historical problems of French thought that symptomatically appear in the flattened picture frame of a self-enclosed visuality such as the Plan Voisin. That is precisely why the Corbusian image in all its idealist glory was instrumentalised, and ironically why Le Corbusier was more useful to le faisceau in transmitting plans that would never be realised beyond the life of the image. As an ideal image-city, the wrongs of French history and great interruption of the revolution could be made right again. In that sense the task of the image was to reverse la decadence, to reverse history, not only for le faisceau but for Le Corbusier himself who believed in the same historiographic mythology as Valois; and this is what makes the visual image dangerous in the hands of fascist ideology. Le Corbusier's image of the modern city in 1927 visualises the alchemical history of the problem of modernity, its transformation from pure mind into action: from the transformation of enlightenment philosophy from Kant and Hegel's response to Kant, to its French translation in the industrial models of Sorel, the anarcho-syndicalist movement, and its savage end in the third reich - the spatio-industrial organisation par excellence that modernised genocide and conceived of mass murder as an architectural regime. French fascism with its roots in romanticism, idealism and anti-enlightenment thought not only contributed to but was fundamental to Le Corbusier's urban formulation that reproduced ideas forged in the reactionary constructs that appeared as early as the French enlightenment, the intellectual laboratory in which philosophical fascism gestated for 200 years. Le Corbusier represents through the disciplinary figure we call "Architecture" the historical event of putting the problems of enlightenment thought into practice aprés Kant and Hegel.

\section{References}

Antliff, M. 1997. La cité française: Georges valois, Le Corbusier, and fascist theories of urbanism, in M. Affron, M. Antliff (Eds.). Fascist visions: Art and ideology in France and Italy. Princeton, N. J.: Princeton University Press.

Antliff, M. 2007. Avant-garde fascism: The mobilization of myth, art, and culture in France, 1909-1939. Duke University Press.

Benjamin, W. 1968. The work of art in the age of mechanical reproduction. Illuminations. New York: Schocken Books.

Bernardi, B. \& Rousseau, J.-J. 2002. Rousseau, discours sur l'économie politique. Vrin.

Brott, S. 2013. Architecture et révolution: Le Corbusier and the fascist revolution. Thresholds, 41.

Coleman, N. 2012. Utopia and modern architecture?, Architectural Research Quarterly 16: 339-348.

Colquhoun, A. 1989. Modernity and the classical tradition: Architectural essays, 1980-1987. MIT Press Cambridge MA.

Fishman, R. 1982. Urban utopias in the twentieth century: Ebenezer Howard, Frank lloyd wright, and Le Corbusier. Cambridge, Mass.: MIT Press.

Gentile, G.; Mussolini, B. 1932. La dottrina del fascismo. Enciclopedia Italiana.

Gentile, G.; Mussolini, B. 1935. The doctrine of fascism (1932), in B. Mussolini. (Ed.). Fascism doctrine and institutions. Rome: Ardita Publishers.

Hegel, G. W. F. 1967a. Lord and bondman, section 190 Phenomenology of spirit (1807). New York: Harper Torchbooks, University of Idaho, Department of Philosophy.

Hegel, G. W. F. 1967b. "On scientific knowledge” section no. 25. Phenomenology of spirit (1807). New York: Harper Torchbooks, University of Idaho, Department of Philosophy [online], [cited 30 May 2016]. Available from Internet: https://www.marxists.org/reference/archive/hegel/phindex.htm

Horkheimer, M.; Adorno, T. W.; Noerr, G. S. 2002. Dialectic of enlightenment: Philosophical fragments. Stanford University Press.

James Jay Hamilton. 1973. Georges Sorel and the inconsistencies of a Bergsonian Marxism, Political Theory 1: 329-340.

Jarcy, X. D. 2015. Le Corbusier, un fascisme Français. Paris: Albin Michel.

Le Corbusier. 1923. L'Esprit Nouveau: Revue internationale illustrée de l'activité contemporaine.

Le Corbusier. 1925a. L'Esprit Nouveau: Revue internationale illustrée de l'activité contemporaine.

Le Corbusier. 1925b. Urbanisme. Paris: Editions Crès.

Le Corbusier. 1968. Étude sur le mouvement d'art décoratif en allemagne. New York: Da Capo Press.

Le Corbusier. 1971. The city of tomorrow and its planning. Cambridge: MIT Press.

Le Corbusier. 1980. Urbanisme. Paris: Les Editions Arthaud.

Le Corbusier. 1995 [1929]. Oeuvre complète: Le Corbusier: 1910-1929. Berlin: Les Editions d'Architecture, Birkhäuser.

Le Corbusier. 1921a. Mass-production houses. L'Esprit Nouveau. 
Le Corbusier, 1921b. Science et industrie. L'Esprit Nouveau, revue internationale hebdomadaire d'economique.

Le Jeune de Boulencourt, 1683. Description générale de l'hostel royal des invalides établi par louis le grand dans la plaine de grenelle près paris, avec les plans, profils et élévations de ses faces, coupes et appartements, in Frontiscipe, V. E. O. C. P., To the Title (Ed.). Paris: Chez l'auteur, Bibliothèque de l'Institut National d'Histoire de l'Art, collections Jacques Doucet.

Mcleod, M. 1983. “Architecture or revolution”: Taylorism, technocracy, and social change, Art Journal 43: 132-147.

Mcleod, M. 1985. Urbanism and utopia: Le Corbusier from regional syndicalism to vichy. Ann Arbor, MI, University Microfilms International.

Mcnamara, A. 1992. Between flux and certitude: The grid in avant-garde utopian thought, Art History 15: 60-79.

Montesquieu, C. D. S. 1949. The spirit of the laws. New York: Hafner Pub. Co.

Neilson, F. 1919. Georges Sorel and syndicalism. The old freedom. New York: B. W. Huebsch.

Perelman, M. 2015. Le Corbusier: Une froide vision du monde. Paris: Michalon.

Remond, R.; Lemerle, P.; Vidalenc, J. 1954. La droite en France de 1815 à nos jours (collection historique). Paris: Aubier.

Richards, S. 2003. Le Corbusier and the concept of self. New Haven: Yale University Press.

Roth, J. J. 1980. The cult of violence: Sorel and the Sorelians. Berkeley: University of California Press.

Rousseau, J.-J. 1789. Article six, déclaration des droits de l'homme et du citoyen, in N. C. Assembly (Ed.).

Rousseau, J.-J. 1829. Lettres de la Montagne. Armand-Aubrée.

Rousseau, J. J. 2005. The social contract or principles of political right (1762). Jon Roland of the Constitution Society.

Rowe, C. 1996. Le Corbusier: Utopian architect, in A. Caragonne (Ed.) As I was saying: Recollections and miscellaneous essays. Cambridge, Mass.: MIT Press.

Sorel, G. 1912. Réflexions sur la violence. Paris: M. Riveère et cie.

Sorel, G. 1928. De l'utilité du pragmatisme. Paris: M. Rivière.

Sorel, G. 1999. Reflections on violence. Cambridge University Press.

Sorel, G.; Hulme, T. E. 1914. Reflections on violence. New York: B.W. Huebsch.

Stanley, J. 1981. The sociology of virtue: The political \& social theories of George Sorel. Berkeley: University of California Press.

Sternhell, Z. 1996. Neither right nor left: Fascist ideology in France. Princeton University Press.

Sutcliffe, A. 1977. A vision of utopia: Optimistic foundations of le corbusier's doctrine d'urbanisme, in R. Walden (Ed.) The open hand. Cambridge, Mass. and London: MIT Press.

Turner, P. 1971. The beginnings of Le Corbusier's education, 1902-07, The Art Bulletin 53: 214-224.

Turner, P. V. 1977. The education of Le Corbusier (Harvard 1971). New York: Garland Pub. Harvard University.

Valois, G. 1927. Le plan voisin, Nouveau Siècle.

Valois, G. 1927a. La nouvélle étape de fascisme, Nouveau Siècle, 1.

Valois, G. 1927b. Le fascisme. Paris: Nouvelle librairie nationale.
Valois, G. 1927c. Sur la voie glorieuse et rude de la pauverté et de la réussite. Nouveau Siècle.

Voltaire. 1762. The sermon on the fifty.

Voltaire. 1996 [1737]. On god, the soul, and innate mortality, letter to Frederick, Prince Royal of Prussia, october 1737. University of Chicago: Voltaire Society of America. [online], [cited 27 May 2016]. Available from Internet: https://www.whitman.edu/VSA/letters/10.1737.html

Weber, E. J. 1964. Varieties of fascism: Doctrines of revolution in the 12th century. D. Van Nostrand Company.

Winter, P. 1927. Les animateurs: Le Corbusier. Nouveau Siècle.

\section{SIMONE BROTT}

Completed a Masters in the History, Theory and Criticism of Architecture and Urbanism at Yale University, followed by a Ph.D. in Architecture at The University of Melbourne, Australia. She is the author of Architecture For a Free Subjectivity: Deleuze and Guattari at the Horizon of the Real (Ashgate 2011) and Architecture Post Mortem: The Diastolic Architecture of Decline, Dystopia, and Death (Ashgate 2013). Currently coordinates history and theory of architecture at Queensland University of Technology, Brisbane. 